UDC 685.34.023.4

T.I. Kulik, $\mathrm{PhD}$, Assoc.Prof.,

O.P. Burmistenkov, DEng, Prof.,

B.M. Zlotenko, DEng, Prof.

Kyiv National University of Technologies and Design, 2 Nemirovich-Danchenko Str., 01011 Kyiv, Ukraine; e-mail: t-81@ukr.net

\title{
STRENGTH AND DEFORMATION OF POLYMER PIECES AT THE LIGHT INDUSTRY
}

Т.І. Кулік, О.П. Бурмістенков, Б.М. Злотенко. Міцність і деформація полімерних деталей легкої промисловості. Стаття присвячена інженерному методу визначення міцності і деформації полімерних деталей легкої промисловості на прикладі підошви взуття. Отримано аналітичні залежності для визначення міцності і прогину консольної балки з в'язко-пружного матеріалу. Отримані залежності дозволяють оцінити поведінку підошви у процесі носіння взуття і прогнозувати його експлуатаційні характеристики. Умови навантаження балки відповідають роботі підошви взуття на високих підборах. При математичному моделюванні навантаження консольної балки враховано властивості матеріалу, які не відповідають закону Гука. Розрахунок на міцність дозволяє визначати оптимальні геометричні параметри підошви, а саме іiї товщину і форму рифлення ходової поверхні, які дозволять уникнути іiі руйнування під дією робочих навантажень. Розрахунок на прогин дозволяє прогнозувати величину деформації підошви відносно каблука в момент іï контакту з грунтом з метою забезпечення необхідної форми взуття.

Ключові слова: міцність, деформація, в'язко-пружне тіло, проектування підошви взуття, експлуатаційні властивості взуття.

T.I. Kulik, O.P. Burmistenkov, B.M. Zlotenko. Strength and deformation of polymer pieces at the light industry. The article is devoted to elaboration of engineering method to evaluate both strength and deformation of polymer details at light industry on the shoe sole example. Analytical dependences for determining the strength and deflection of a cantilever beam made of viscoelastic material are obtained. These dependences allow to estimate the behavior of the shoe soles with high heels while wearing the shoes. In mathematical modeling of cantilever beam load the material properties that do not meet Hooke's law are taken into account. Strength calculations provide the possibility to determine the sole's optimal geometric parameters, namely its thickness and the shape of the running surface corrugations. Deflection calculations allow predicting the sole deformation value respectively to the heel at the time of its contact with the ground surface to ensure shoes form stability.

Keywords: strength, deformation, viscoelastic body, shoe sole design, shoe performance properties.

Introduction. Today, polymer materials are widely used by various industries, especially in machine building engineering, civil building, light industry and the production of packaging materials [1]. In the shoe industry almost all bottom shoes' parts are made of polymers. Such components must meet several requirements: the shoes sole should be both resilient and flexible and have sufficient rigidity and strength. Providing enough strength is important in the shoes design as the sole is prone to different types of stress, such as multiple bending (with different areas constantly stretched and compressed), sole surface multiple compression when walking and dynamic stress when jumping and running. Thus, the details accurate design with regard to these factors will increase their strength and improve the product quality $[2,3]$.

Literature review. Designing product parts at light industry is complicated by the fact that they are made mainly of artificial and synthetic polymer materials which are not elastic bodies, therefore impossible being to apply here the methods of materials strength and elasticity theory [4, 5].

Using the viscoelasticity theory methods leads to considerably complicated calculations imposing the account of load or deformation timing mode.

The Aim of the Research is to develop engineering methods of light industry parts calculation, based on the known relation function between the polymer materials' strains and stresses:

DOI 10.15276/opu.2.46.2015.12

(C) 2015 The Authors. This is an open access article under the CC BY license (http://creativecommons.org/licenses/by/4.0/). 


$$
\sigma^{m}=E \varepsilon,
$$

where $m$ - degree varying from 0,6 to 1 (at $m=1$ the body demonstrates its elasticity);

$\sigma$ - stress;

$\varepsilon-$ strain

Main Body. We proceed to study the clear bean bending (Fig. 1), characterized with $m \neq 1$.

The equilibrium condition implies that

$$
\begin{gathered}
\Sigma X=0 \text { or } \int_{A} \sigma d A=0, \\
\Sigma M_{y}=0, \quad M-\Sigma d N z=0 \text { or } \quad M-\int_{A} \sigma z d A=0,
\end{gathered}
$$

thus

$$
\begin{gathered}
\int_{A} \sigma z d A=M, \\
\Sigma M_{z}=0, \quad \Sigma d N y=0 \text { or } \quad \int_{A} \sigma y d A=0,
\end{gathered}
$$

where $M$ - bending moment;

$\sigma$ - normal stress.

The beam's element shape prior to load and after distortion is shown at Fig. 2.

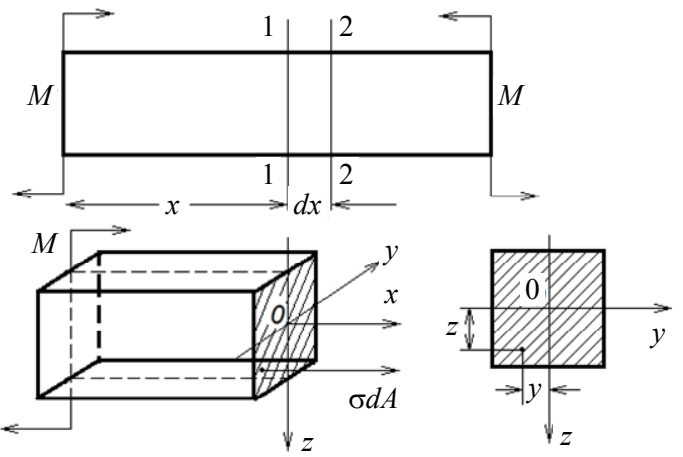

Fig. 1. Diagram of bent beam load
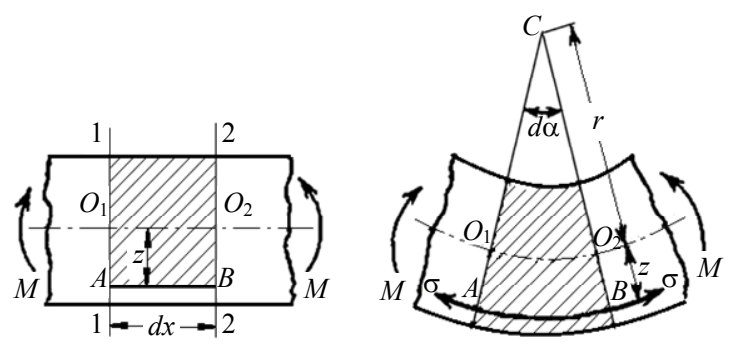

Fig 2. Beam element: prior and after the distortion

Initial length of the fiber $A B$, positioned at the distance $z$ from the neutral axis and elongated when influenced by stress $\sigma$

$$
d x=\cup O_{1} O_{2}=r d \alpha,
$$

where $r$ - beam curvature radius;

$\alpha$ - central angle.

After distortion the length

$$
\cup A B=(r+z) d \alpha .
$$

Absolute elongation of the fiber

$$
\Delta l=(r+z) d \alpha-r d \alpha=z d \alpha .
$$

Where from the respective elongation [2]

$$
\varepsilon=\frac{z d \alpha}{r d \alpha}=\frac{z}{r} .
$$

From (1) we get

$$
\sigma=(E \varepsilon)^{\frac{1}{m}}
$$


Introducing (3) at (4)

$$
\sigma=\left(E \frac{z}{r}\right)^{\frac{1}{m}}
$$

Introducing (5) at (2):

$$
\int_{A}\left(E \frac{z}{r}\right)^{\frac{1}{m}} z d A=M
$$

either

$$
\left(\frac{E}{r}\right)^{\frac{1}{m}} \int_{A} z^{\frac{1}{m}+1} d A=M
$$

Identifying the integral (6)

$$
I_{m}=\int_{A} z^{\frac{1}{m}+1} d A
$$

Taking into account (6) and (7)

$$
\left(\frac{E}{r}\right)^{\frac{1}{m}} I_{m}=M \quad \text { or }\left(\frac{E}{r}\right)^{\frac{1}{m}}=\frac{M}{I_{m}} .
$$

To estimate stresses, we reduce (5) to the form

$$
\left(\frac{E}{r}\right)^{\frac{1}{m}}=\frac{\sigma}{z^{\frac{1}{m}}}
$$

Introducing (9) at (8)

$$
\sigma=\frac{M z^{\frac{1}{m}}}{I_{m}} .
$$

Defining

$$
Z=\frac{I_{m}}{z^{\frac{1}{m}}}
$$

With the account of (10) and (11)

$$
\sigma=\frac{M}{Z} .
$$

To evaluate distortions, we rewrite the (8) as

$$
\frac{1}{r}=\frac{M^{m}}{E I_{m}{ }^{m}} .
$$

Considering the beam distortion diagram (Fig. 3) the unit length of the bent beam's axis will be [2]

$$
d s=r d \theta \text { and } \frac{1}{r}=\frac{d \theta}{d s} .
$$

Admissible is the approximation

$$
\begin{gathered}
d s \approx d x, \\
\theta \approx \tan \theta=\frac{d y}{d x} .
\end{gathered}
$$


Differentiating (15) we obtain

$$
\frac{d \theta}{d x} \approx \tan \theta=\frac{d^{2} y}{d x^{2}} .
$$

With the account of (14) and (16) the expression (13) can be written as

Introducing (17) at (12)

$$
\frac{1}{r}=\frac{d^{2} y}{d x^{2}}
$$

$$
E I_{m} \frac{d^{2} y}{d x^{2}}=M^{m} .
$$

Now we determine the cantilever beam distortion parameters under concentrated force applied to its free end. Considering that the increment $d x$ corresponds to the decrement $d y$, the bending moment

Introducing (19) at (18)

$$
M=-P(l-x) \text {. }
$$

$$
E I_{m} y^{\prime \prime}=[-P(l-x)]^{m} \text {. }
$$

Upon variables' deployment at (20) with further integration we get

$$
E I_{m} y^{\prime}=(-P)^{m} \int(l-x)^{m} d x=P^{m} \int(x-l)^{m} d(x-l)=P^{m} \frac{1}{m+1}(x-l)^{m+1}+C .
$$

When initial conditions $x=0, y^{\prime}=0$ the constant value

$$
C=-P^{m} \frac{1}{m+1} l^{m+1} .
$$

Introducing (22) at (21)

$$
E I_{m} y^{\prime}=P^{m} \frac{1}{m+1}(x-l)^{m+1}-P^{m} \frac{1}{m+1} l^{m+1}=-P^{m} \frac{1}{m+1}\left[l^{m+1}-(x-l)^{m+1}\right] .
$$

With respect to (1) from (23) the beam section rotation angle will be

$$
\theta=y^{\prime}=-\frac{P^{m}}{(m+1) E I_{m}}\left[l^{m+1}-(x-l)^{m+1}\right] .
$$

Detailing the variables at (21) with further integration we get

$$
\begin{gathered}
E I_{m} y=P^{m} \frac{1}{m+1} \int(x-l)^{m+1} d x+\int C d x=P^{m} \frac{1}{m+1} \int(x-l)^{m+1} d(x-l)+\int C d x= \\
=P^{m} \frac{1}{(m+1)(m+2)}(x-l)^{m+2}+C x+D .
\end{gathered}
$$

When initial conditions $x=0, y=0$ the constant value is

Introducing (25) and (22) at (24), we get

$$
D=P^{m} \frac{1}{(m+1)(m+2)} l^{m+2} .
$$

$$
\begin{gathered}
E I_{m} y=P^{m} \frac{1}{(m+1)(m+2)}(x-l)^{m+2}-P^{m} \frac{1}{m+1} l^{m+1} x+P^{m} \frac{1}{(m+1)(m+2)} l^{m+2}= \\
=-P^{m} \frac{1}{(m+1)(m+2)}\left[(m+2) l^{m+1} x-l^{m+2}-(x-l)^{m+2}\right] .
\end{gathered}
$$

From (26) the formula for the beam curvature is

$$
y=-\frac{P^{m}}{(m+1)(m+2) E I_{m}}\left[(m+2) l^{m+2} x-l^{m+2}-(x-l)^{m+2}\right] .
$$

Let us consider the cantilever beam distortion under even-distribution load (Fig. 4). 


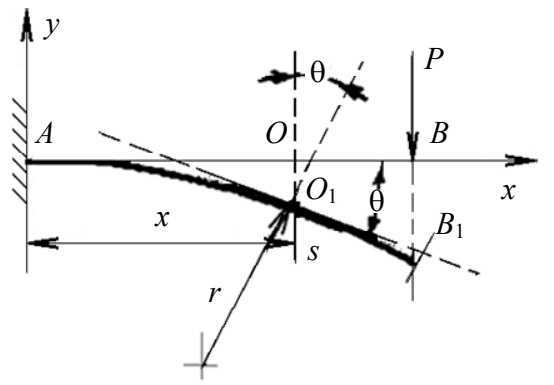

Fig. 3.Diagram of a cantilever beam distortion under concentrated force applied to its free end

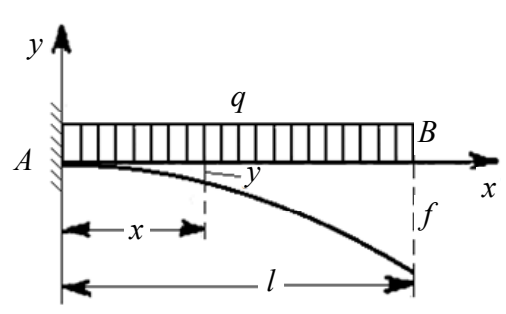

Fig. 4. Diagram of a cantilever beam distorted with the evenly distributed load

At such a case the distorting moment

$$
M=-q \frac{(l-x)^{2}}{2} .
$$

Introducing (27) at (18)

$$
E I_{m} y^{\prime \prime}=\left[-q \frac{(l-x)^{2}}{2}\right]^{m}
$$

The variables at (28) being developed with further integration, we obtain

$$
E I_{m} y^{\prime}=\left(-\frac{q}{2}\right)^{m} \int(l-x)^{2 m} d x=\frac{q^{m}}{2} \int(x-l)^{2 m} d(x-l)=\left(\frac{q}{2}\right)^{m} \frac{1}{2 m+1}(x-l)^{2 m+1}+C
$$

When initial conditions $x=0, y^{\prime}=0$ the constant value

$$
C=-\left(\frac{q}{2}\right)^{m} \frac{1}{2 m+1} l^{2 m+1} .
$$

Introducing (30) at (29)

$$
E I_{m} y^{\prime}=\left(\frac{q}{2}\right)^{m} \frac{1}{2 m+1}(x-l)^{2 m+1}-\left(\frac{q}{2}\right)^{m} \frac{1}{2 m+1} l^{2 m+1}=-\left(\frac{q}{2}\right)^{m} \frac{1}{2 m+1}\left[l^{2 m+1}-(x-l)^{2 m+1}\right] .
$$

With the account of (15) from (31) we get the beam section rotation angle

$$
\theta=y^{\prime}=-\frac{q^{m}}{2^{m}(2 m+1) E I_{m}}\left[l^{2 m+1}-(x-l)^{2 m+1}\right] .
$$

Developing the variables at (29) with further integration we obtain

$$
\begin{gathered}
E I_{m} y^{\prime}=\left(\frac{q}{2}\right)^{m} \frac{1}{2 m+1} \int(x-l)^{2 m+1} d x+\int C d x=\left(\frac{q}{2}\right)^{m} \frac{1}{2 m+1} \int(x-l)^{2 m+1} d(x-l)+\int C d x= \\
=\left(\frac{q}{2}\right)^{m} \frac{1}{(2 m+1)(2 m+2)}(x-l)^{2 m+2}+C x+D .
\end{gathered}
$$

When initial conditions $x=0, y=0$ the constant value

$$
D=\left(\frac{q}{2}\right)^{m} \frac{1}{(2 m+1)(2 m+2)} l^{2 m+2} .
$$

Introducing (33) and (30) at (32)

$$
\begin{gathered}
E I_{m} y=\left(\frac{q}{2}\right)^{m} \frac{1}{(2 m+1)(2 m+2)}(x-l)^{2 m+2}-\left(\frac{q}{2}\right)^{m} \frac{1}{2 m+1} l^{2 m+1} x+\left(\frac{q}{2}\right)^{m} \frac{1}{(2 m+1)(2 m+2)} l^{2 m+2}= \\
=-\left(\frac{q}{2}\right)^{m} \frac{1}{(2 m+1)(2 m+2)}\left[(2 m+2) l^{2 m+1}-l^{2 m+2}-(x-l)^{2 m+2}\right] .
\end{gathered}
$$


From (34) the beam curvature formula

$$
y=\frac{q^{m}}{2^{m}(2 m+1)(2 m+2) E I_{m}}\left[(2 m+2) l^{2 m+2}-l^{2 m+2}-(x-l)^{2 m+2}\right] .
$$

Case of cantilever beam free end and concentrated force applied

$$
\begin{gathered}
\theta_{\text {max }}=-\frac{P^{m} l^{m+1}}{(m+1) E I_{m}}, \\
f=y_{\text {max }}=-\frac{P^{m} l^{2 m+1}}{(m+2) E I_{m}} .
\end{gathered}
$$

Case of cantilever beam free end and distributed force applied

$$
\begin{gathered}
\theta_{\max }=-\frac{q^{m} l^{2 m+1}}{2^{m}(2 m+1) E I_{m}}, \\
f=y_{\max }=\frac{q^{m} l^{2 m+2}}{2^{m}(2 m+2) E I_{m}} .
\end{gathered}
$$

The integral (7) for rectangular cross-section beam (Fig. 5)

$$
I_{m}=\int_{A} z^{\frac{1}{m}+1} d A=\int_{-h / 2}^{h / 2} z^{\frac{1}{m}+1} b d z=b \int_{-h / 2}^{h / 2} z^{\frac{1}{m}+1} d z=\frac{b}{\frac{1}{m}+2}\left[z^{\frac{1}{m}+2}\right]_{-h / 2}^{h / 2}=\frac{2 b}{\frac{1}{m}+2}\left(\frac{h}{2}\right)^{\frac{1}{m}+2} .
$$

Introducing (39) at (10)

$$
\sigma=\frac{M\left(\frac{1}{m}+2\right) z^{\frac{1}{m}}}{2 b\left(\frac{h}{2}\right)^{\frac{1}{m}+2}} .
$$

The stress at fiber most distant from the neutral axis (position with) $z=h / 2$,

$$
\sigma=\frac{2 M\left(2+\frac{1}{m}\right)}{b h^{2}} \text {. }
$$

Introducing (39) at (35) ... (38)

$$
\begin{gathered}
\theta_{\max }=-\frac{P^{m} l^{m+1}}{(m+1) E \frac{2 b}{\frac{1}{m}+2}\left(\frac{h}{2}\right)^{\frac{1}{m}+2}}, f=y_{\max }=-\frac{P^{m} l^{2 m+1}}{(m+2) E \frac{2 b}{\frac{1}{m}+2}\left(\frac{h}{2}\right)^{\frac{1}{m}+2}}, \\
\theta_{\max }=-\frac{q^{m} l^{2 m+1}}{2^{m}(2 m+1) E \frac{2 b}{\frac{1}{m}+2}\left(\frac{h}{2}\right)^{\frac{1}{m}+2}}, f=y_{\max }=\frac{q^{m} l^{2 m+2}}{2^{m}(2 m+2) E \frac{2 b}{\frac{1}{m}+2}\left(\frac{h}{2}\right)^{\frac{1}{m}+2}} .
\end{gathered}
$$

Results. To avoid the sole's unacceptable deformations and destruction at its attachment to the heel point, we can determine its desired thickness, knowing all other geometric parameters of the produced footwear and the human expected weight (Fig. 6). 


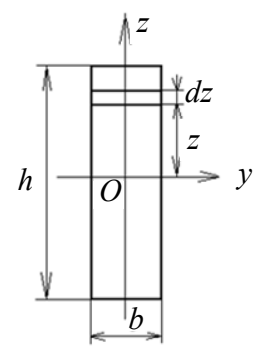

Fig. 5. Rectangular cross-section beam diagram

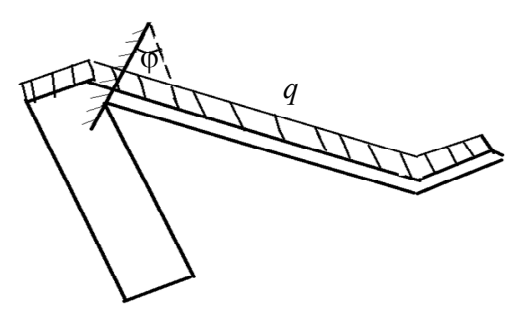

$a$

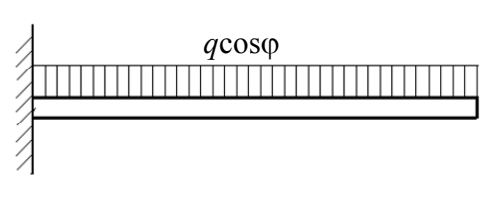

$b$

Fig 6. Diagram of the sole loading (a) and equivalent diagram of cantilever beam (b)

The shoe sole can be represented schematically as a beam which width essentially exceeds the height and is equal to averaged lengthwise value.

Conclusions. The obtained dependencies can be used in the analysis of shoe sole loads during footwear further wearing process.

\section{Література}

1. Chanda, M. Industrial polymers, specialty polymers, and their applications / M. Chanda, S.K. Roy. Boca Raton, FL: CRC Press, 2009. - 432 p.

2. Омельченко, Н.М. Взуття та здоров’я людини / Н.М. Омельченко, В.П. Кернеш, В.П. Коновал // Легка промисловість. - 2009. - № 2. - С. $38-39$.

3. Катрич, В. Взуття для дітей дошкільного віку: надійність 3 позиції якості матеріалів / В. Катрич // Стандартизація. Сертифікація. Якість. - 2010. — № 1(62). — С. $62-65$.

4. Physical properties of polymers handbook / ed. by J.E. Mark. - $2^{\text {nd }}$ Ed. - New York: Springer, 2007. $-723 \mathrm{p}$.

5. Importance of the surface treatment in the peeling strength of joints for the shoes industry [Електронний ресурс] / R.M.M. Paiva, E.A.S. Marques, L.F.M. da Silva, M.A.P. Vaz // Applied Adhesion Science. - 2013. - Vol. 1. — Режим доступу: http://www.appliedadhesionscience.com/content/1/1/5 (Дата звернення: 02.02.2015).

\section{References}

1. Chanda, M. and Roy, S.K. (2009). Industrial Polymers, Specialty Polymers, and Their Applications. Boca Raton, FL: CRC Press.

2. Omelchenko, N.M., Kernesh, V.P. and Konoval, V.P. (2009). The footwear and human health. Light Industry, 2, 38-39.

3. Katrych, V. (2010). Pre-school children's shoes: reliability in terms of materials quality. Standardization. Certification. Quality, 1, 62-65.

4. Mark, J.E. (Ed.). (2007). Physical Properties of Polymers Handbook ( $2^{\text {nd }}$ Ed.). New York: Springer.

5. Paiva, R.M.M., Marques, E.A.S., da Silva, L.F.M. and Vaz, M.A.P. (2013). Importance of the surface treatment in the peeling strength of joints for the shoes industry. Applied Adhesion Science, 1. Retrieved from $\mathrm{http}: / / \mathrm{www}$.appliedadhesionscience.com/content/1/1/5 